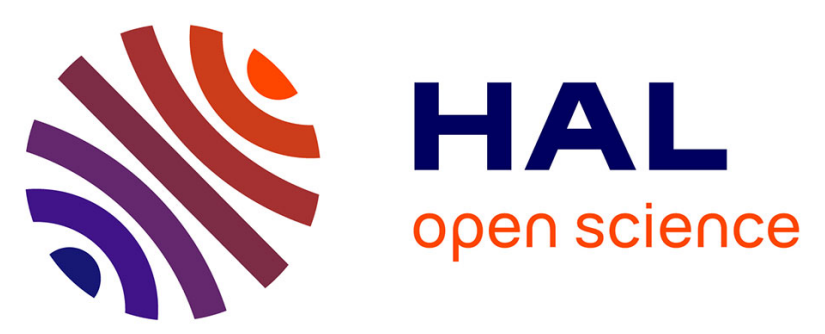

\title{
Evaluation of biobank constitution and use: multicentre analysis in France and propositions for formalising the activities of research ethics committees.
}

Sandrine de Montgolfier, Grégoire Moutel, Nathalie Duchange, Ingrid Callies, Lama I. Sharara, Catherine Beaumont, Josué Feingold, Christian Hervé

\section{To cite this version:}

Sandrine de Montgolfier, Grégoire Moutel, Nathalie Duchange, Ingrid Callies, Lama I. Sharara, et al.. Evaluation of biobank constitution and use: multicentre analysis in France and propositions for formalising the activities of research ethics committees.. European Journal of Medical Genetics, 2006, 49 (2), pp.159-67. 10.1016/j.ejmg.2004.12.002 . inserm-00255903

\section{HAL Id: inserm-00255903 https://www.hal.inserm.fr/inserm-00255903}

Submitted on 1 Feb 2011

HAL is a multi-disciplinary open access archive for the deposit and dissemination of scientific research documents, whether they are published or not. The documents may come from teaching and research institutions in France or abroad, or from public or private research centers.
L'archive ouverte pluridisciplinaire HAL, est destinée au dépôt et à la diffusion de documents scientifiques de niveau recherche, publiés ou non, émanant des établissements d'enseignement et de recherche français ou étrangers, des laboratoires publics ou privés. 
Evaluation of biobank constitution and use: multicentre analysis in France and propositions for formalising the activities of research ethics committees

Sandrine de Montgolfier, Grégoire Moutel, Nathalie Duchange, Lama Sharara, Catherine Beaumont, Josué Feingold and Christian Hervé

Laboratoire d'éthique médicale et médecine légale \& Institut International de Recherche en Ethique Biomédicale (IIREB). Faculté de Médecine de Paris 5. 45 rue des Saints-Pères 75006 Paris, France

www.inserm.fr/ethique

Correspondence to: Dr Grégoire Moutel

Laboratoire d'éthique médicale et médecine légale

Faculté de Médecine de Paris 5

45 rue des Saints-Pères, 75006 Paris, France

Tel: +33(0)1 42864135 -fax: +33(0)1 42864133

moutel@necker.fr 
Page 2

\begin{abstract}
Biobanks are collections of biological material and related files gathered and stored for clinical or research purposes. Here, we investigated the questions raised during the evaluation of biobanks by biomedical Research Ethics Committees (RECs), particularly in the context of genetic research. We sent a questionnaire to all RECs in France to survey their concerns and the ethical criteria used when evaluating research involving the storage of biological samples. Most of the RECs think that they should be consulted to evaluate the constitution of biobanks. The proportion of RECs of this opinion depended on whether the biobank is being constituted in the absence of an associated research project (initially created for clinical purposes or for undefined research) $(14 / 28)$, whether the biobank is being constituted for research use (21/28) or whether an existing research biobank is being re-used (19/28). Views diverged concerning the way ethics principles are applied, showing that REC evaluations of biobanks might be formalised at each of the following steps: constitution, use and re-use. In this paper, we suggest concrete elements that could be integrated into the application of the new French law concerning the protection of the human beings participating in research as well as into international recommendations.
\end{abstract}

Key words: Biobanks, Research Ethics Committee, Biomedical Research, Informed Consent, Human Biological Resources, Genetic Databases. 


\section{INTRODUCTION}

Historical grounds, together with the development of biomedical research involving humans, led to the institution of Ethics Committees. These committees were officially created in 1975 in the Helsinki Declaration [29].

In France, a law passed in 1988 [13] led to the constitution of research ethics committees (RECs) for the protection of persons participating in biomedical research. There are now 48 such committees, each serving a defined geographical area. These committees are independent in their selection of members and in their finances. Members are drawn from groups representative of medical research, medical practitioners, universities, various major disciplines, and law. The recommendations formulated by the committees are transmitted to the Ministry of Health, which can independently review an opinion when judged necessary $[13,14]$. The role of the committees, as defined by law, is to evaluate the validity of research, particularly as concerns: the protection of participants, informed consent of participants, methods of obtaining consent, financial compensation, general relevance of the project and whether the available means and the qualifications of the investigators involved are appropriate to meet the aims.

All biomedical research must be approved by an REC. It is not clear whether the evaluation of biobanks is part of the mission of the RECs and if so, in what way. A biobank can be defined as a group of biological samples (or biological by-products) that may consist of solid tissues, blood, saliva, or any other tissue or fluid containing nucleated cells. The biological samples are associated with files, often computerised, that may include the origin of the donors, clinical data and biological data. $[4,6,11]$. These data may be identified, identifiable, directly anonymous or anonymised [18]. The way in which the files are handled differs according to the type of research. The term "biobank" covers all of the 
activities concerning the management of human biological samples and files including their transfer and access.

Following the development of biobanks, French official reports suggested that RECs should evaluate the constitution and storage of biological samples. In 1994, the Louisot Report [22] stated that "...the constitution of the collection... requires the opinion of the REC" and in 1998, the report of the French National Consultative Ethics Committee (CCNE) stated that “...this agreement will take into account measures involved in the collection, storage and abusive use (such as use in the context of employment, insurance ...) of samples and any information concerning them" [5].

A number of studies have highlighted the ethical and legal issues raised by the constitution of biobanks, including the organisational and medical responsibilities $[3,8,9,10,23,24]$. We have previously evaluated $[4,27]$ how the French RECs feel they are and should be involved in the constitution and use of biobanks, which ethical rules they believe are essential for the protection of persons and to what extent this is integrated into current practice. The aim of the present study was to identify current difficulties in the functioning of the committees. We used a questionnaire to examine whether the RECs consider that the constitution of a biobank requires their approval. Twenty-five of the 28 RECs that answered think that they should be consulted for the constitution of biobanks, but in practice, only 18 conduct such evaluations. The RECs believe that they should, and do, consider the content of the consent form, the information given to participants and confidentiality. Interestingly, elements such as uses of a biobank, its fate at the end of the study and the ways in which research results are communicated to participants are not evaluated although RECs think that they should be.

The goal of the present study is to define the roles and means of the RECs in the evaluation of biobanks. Our results focus first on the way RECs evaluate different types of biobank in 
the context of human genetics research, and second, on proposals that can be made to formalise these evaluations.

\section{METHODS}

Data were collected from the questionnaire between 2001 and 2002 and analysed in 2003. We used a questionnaire with open and closed questions that had been validated by a multidisciplinary team working in the Laboratory of Medical Ethics at the Paris 5 Faculty of Medicine (see table I). It was approved by the national REC conference chairman and by six previous REC members. A letter was sent with the questionnaire to explain the aims of the study, the definition used for biobanks, references to French recommendations [5, 22] and laws relevant to the study. The questionnaire was sent with a stamped self-addressed envelope to the president of each of the 48 French RECs. Replies to the closed questions were analysed using Excel software. For open questions, the content of the text was analysed by the research team with expertise in genetics and bioethics to extract relevant citations highlighting the issues addressed here. The proposals concerning the evaluation of biobanks by RECs were complied by using the replies to this open questions, discussions with experts (CCPPRB members, CCNE members, research team members, institutional members), our expertise in the field $[2,4,9,21,27]$ and by analysing international literature (publications, reports and proposals).

\section{RESULTS}

\subsection{Questionnaire survey}

Twenty-eight of the 48 RECs $(58.3 \%)$ completed the questionnaire. This response rate is similar to those obtained in similar studies $[15,26]$. This rate indicates that many RECs are concerned and want to contribute to the evaluation of practices. 
Question 1 asked whether the RECs should be consulted prior to the constitution of biobanks. RECs were almost unanimous (21/28) in answering that they should be consulted for the constitution of any biobank as part of a defined research project. Most of them (19/28) believe that an REC should be consulted for every new research project using samples from an existing research biobank either for a similar study or for a different type of study. Opinions were divided (14/28) concerning the constitution of biobanks without an associated research project at the origin.

Question 2 asked whether the RECs feel a special responsibility concerning their mission in the evaluation of biobanks. Two contrasting attitudes were expressed:

- The strict limitation of the competences of the RECs as stated by the law, the main argument being that the multiplication of opinions leads to increased inertia.

- An extended view, which recommends that this field of research should be part of the REC's field of competence and responsibility despite their current lack of resources (time and human resources).

The following questions dealt with cases the RECs encountered in practice.

To question 3, 14 of the 28 RECs replied that they knew precisely how many files they had handled involving the constitution and use of a biobank.

In question 4 , only 7 of these 14 RECs reported the percentage of files handled that concerned biobanks (between 5\% and 10\%). The percentage has not changed over the last three years. Three members of REC spontaneously reported that some biomedical research projects involve biobanks that are not visible in the project proposals presented to the RECs. For example, clinical projects can include sampling and storage activities that are not explicitly called a biobank by the investigators.

Answers to question 5 show that fourteen of the 28 RECs believed that biobanks are being used in their geographical region without their prior evaluation. 
Question 6 asked whether the RECs have dealt with files concerning the constitution of biobanks without an associated research project. This seems to be a rare event.

In response to question 7, the three RECs concerned explained that they didn't feel competent to evaluate this kind of biobank, but that they had a role in helping the investigators to handle ethical issues.

To question 8,25 of the 28 RECs replied that they would agree to participate in a study aiming to analyse the files they handle concerning the constitution or the use of biobanks. This shows their interest in evaluating their own practices.

\subsection{Proposals}

On the basis of the literature $[1,3,5,7,10,11,12,18,19,20,25]$ and our results $[4,9,21$, 27], we conclude that it is necessary to formalise the role of the committees in this field (Figure 1). The life of a biobank can be broken down into four stages: (1) constitution, (2) storage, (3) first use and (4) fate, including (4a) destruction or anonymisation, (4b) distant use and (4c) delocalisation to an organisation specialised in the conservation, transfer and supply of biobanks.

Three main situations should be considered by RECs for evaluation:

- the constitution of any biobank: samples collected for biomedical research, requalified clinical samples (for example blood samples collected for medical care purposes re-used for research) and samples collected from different geographical areas (national or international), whether from private or public institutions for their own research programme or for any activity involving the conservation, transfer and supply of biobanks. 
- the setting up of any research protocol (primary or secondary use) involving use of a pre-existing biobank. In a number of cases the constitution of the biobank and the setting up of the research project will be associated in the evaluation by the REC.

- $\quad$ any event affecting the biobank (transfer, destruction, anonymisation).

To simplify the evaluation procedures two different REC evaluation procedures could be organised: an initial procedure at the constitution of the biobank whether or not this is associated with a research project, and a simplified procedure (follow-up) for all other cases.

At the constitution step, three fundamental points should be evaluated:

- the information given to the donor

- the modalities for consent before sample collection

- the relevance of the scientific research requiring the creation of the biobank.

To define more precisely the analysis of these points, the following elements should be considered from now on: time given to the participant between information and consent, possibility to withdraw from the study at any time, estimated duration of storage, level of confidentiality for personal data, choice of the population studied in the context of the relevance of the scientific project (to avoid unnecessary inclusion of high-risk populations and to optimise existing biobanks) and fate of a biobank.

Whenever a biobank is used or re-used, the following series of items should be evaluated:

- Concordance with the initial consent: new orientation of scientific choices, geographical transfer, modification of the level of confidentiality. If these conditions are not fulfilled, the REC should propose to seek new consent or to make the samples anonymous.

- Result feedback: in all cases, global result feedback to the participants should be considered, as should the modalities by which this could be achieved. RECs could 
play a role in evaluating how the research team addresses these questions and their practical application.

- Level of confidentiality: a modification may be required in some cases e.g. for a new study distinct from the first scientific project. Anonymisation of the samples will prevent any further data from being added to the biobank and the possibility of individual feedback. The role of the REC could be to evaluate the pertinence of such choices by considering the initial information and consent as well as the obstacles to obtaining new consent relevant to the new project.

\section{DISCUSSION}

Our findings indicate that the RECs generally feel that their opinion is necessary for the constitution of biobanks, particularly DNA banks, and that they have a particular responsibility regarding the re-use of existing samples [27]. Unlike classical therapeutic trials, new biomedical activities are not necessarily evaluated by a REC. This was the case for ICSI (Intracytoplasmic Sperm Injection), which was not subject to any control by RECs [26]. Therefore, it may be necessary to define how the use of tools such as DNA biobanks in new practices may be potentially harmful to the individual to ensure appropriate means of protection.

Our results show that there is a difference between the activity of RECs in practice and the way they consider their role. This could be explained by the existence of different situations related to the constitution and use of biobanks, and by a lack of regulations adapted to each case.

According to a report published in 2001 and to our results [15], it appears that the RECs are not always consulted for the constitution of biobanks, particularly when no research project is associated. Nevertheless, on the basis of our results, we consider that ethical evaluation is 
essential to ensure that samples and associated data are collected, stored and used correctly, that they remain confidential and that their fate at the end of the study is traced [21]. Accordingly, recent international propositions recommended the evaluation of biobanks by RECs. The European Society of Human Genetics stated that "when it [DNA banking] is for research use, ethical committee oversight is required" [11]. In the International Declaration on Human Genetic Data, the United Nations Educational, Scientific and Cultural Organisation (UNESCO) also proposed that "Ethics committees at institutional or local levels should be consulted as regard to collections in their application to specific research projects" [28]. Finally, the revised French bioethics laws published in August 2004 specify that RECs must be consulted every time a biobank is constituted or re-used for a purpose different from that covered by the initial consent $[14,17]$. This law also specifies that RECs must evaluate the way ethical principles are applied in practice by considering: "the quality of the information given to the participants, the methods for collecting consent, and the ethical and scientific relevance of the project". Therefore, this law proposes that the committees give an opinion at each essential phase of the life of a biobank: constitution, primary use, and re-use with novel scientific finalities. This can be considered as a major breakthrough in the field of biobanks. Rules and guidelines to assist the practical setting up of the general principles written in the law must now be established by taking into consideration results from studies like this one. For example, such recommendations should allow more clear and concrete definition of concepts from the law such as quality of information. We feel it is essential to ensure that all ethical issues concerning biobanks are considered

In conclusion, our results and proposals might contribute towards the development of national and international guidelines [21]. If they are to be effective, these guidelines must be adapted to the practical reality of routine use. If based upon international grounds, the 
guidelines would allow a better view of the functioning of these precious tools for the development of scientific and medical knowledge.

\section{ACKNOWLEDGEMENTS}

We would like to thank all the members of the French RECs who took the time to answer the questionnaire.

We thank members of the Genopole of Evry, of the Inserm and ANRS Institutions, of the CCNE and of the French Ministry of Research for helpful discussions.

\section{REFERENCES}

1. Beskow LM, Burke W, Merz JF, et al. Informed consent for population-based research involving genetics. JAMA 2001; 286(18):2315-21.

2. Callies I., de Montgolfier S., Moutel G., Hervé C. Enjeux éthiques des collections d'échantillons humains dans le cadre de la recherche. Droit Déontologie et soins. 2004, Juin, Volume 4 No 2.

3. Cambon-Thomsen A. 2003. [Biological sample banks: ethical and legal aspects. General Introduction]. Rev Epidemiol Sante Publ 51:99.

4. Cazé-de Montgolfier, S. Collecte, stockage et utilisation des produits du corps humain dans le cadre de recherches en génétique : état des lieux historique, éthique et juridique. Analyse des pratiques au sein des biothèques. Thèse d'éthique médicale et biologique, Paris V. 2002, www.inserm.fr/ethique

5. CCNE. Opinion $\mathrm{N}^{\circ} 60$. Re-examination of the law on bioethics. France: Comité Consultatif National d'Ethique, 1998 : www.ccne-ethique.fr.

6. CCNE. Opinion $\mathrm{N}^{\circ} 77$. Ethical issues raised by collections of biological material and associated information data: "biobanks", "biolibraries. 2003: www.ccne-ethique.fr. 
7. CEE. Directive 95/46/EC of the European Parliament and of the Council of 24 October 1995 on the protection of individuals with regard to the processing of personal data and on the free movement of such data, Official Journal 1995; L 281: 31 - 50.

8. Charru A, Janiaud P. Cahier des charges pour les banques d'ADN, de cellules et de tissus à usage de recherche et de diagnostic: AP-HP/INSERM, 1996.

9. de Montgolfier S., Moutel G., Duchange N., Theodorou I., Herve C., Leport C. et al. Ethical Reflexions on pharmacogenetics and DNA banking in a cohort of HIV-infected patients. Pharmacogenetics 2002; 12 (9): 667-675.

10. Deschenes M, Cardinal G, Knoppers BM, Glass KC. Human genetic research, DNA banking and consent: a question of 'form'? Clin Genet 2001; 59(4):221-39.

11. European Society of Human Genetics. Recommendations of the European Society of Human Genetics. Data storage and DNA banking for biomedical research: technical, social and ethical issues. Eur. J. Hum. Genet. 2003, 11 Suppl 2, S8-S10.

12. France. Law $\mathrm{N}^{\circ} 2004-801$ of August 6 th, 2004 on the processing of nominative data with the objective of research in the health field and amending law $\mathrm{N}^{\circ} 78-17$ of 6 January,1978 on informatics personal card-indexes and freedom. Journal Officiel 2004; 7 août 2004:14063. www.legifrance.gouv.fr.

13. France. Law $\mathrm{N}^{\circ} 88-1138$ of December $20^{\text {th }}, 1988$ on the protection of persons accepting biomedical research (Huriet-Sérusclat Law) revised July 25th, 1994. Journal Officiel 26 juillet 1994:10747-49, www.legifrance.gouv.fr.

14. France. Law $\mathrm{N}^{\circ} 2004-806$ of august $9^{\text {th }}, 2004$ on biomedical research. Journal Officiel 11 août 2004: 14277, www.legifrance.gouv.fr

15. France. Rapport du Sénat $\mathrm{N}^{\circ} 267$ de C. Huriet sur le fonctionnement des REC. France, Sénat, 2001, www.senat.fr 
16. France. Law $\mathrm{N}^{\circ} 2002-303$ of the $4^{\text {th }}$ March, 2002 on patient rights and quality of health system. Journal Officiel 2002, 5 mars 2002:4118. www.legifrance.gouv.fr

17. France. Law $n^{\text {o }} 2004-800$ of august $6^{\text {th }}, 2004$ on bioethics. Journal Officiel du 7 août 2004 : 14140. www.legifrance.gouv.fr

18. Godard B., Schmidtke J., Cassiman J-J., Ayme S. Data storage and DNA banking for biomedical research: informed consent, confidentiality, quality issues, ownership, return of benefits. A professional perspective. Eur. J. Hum. Genet. 2003, 11 Suppl 2, S88-S122.

19. Hirtzlin I., Dubreuil C., Préaubert N. \& al. An empirical survey on biobanking of human genetic material and data in six EU countries. Eur. J. Hum. Genet. 2003, 11, 475488.

20. Knoppers, B.M., Population genetics and benefit sharing. Community Genet, (2001), 3(4): p. 212-4.

21. Le Roux N., de Montgolfier S., di Donato J.-H., Boccon-Gibod L., Teillac P., Hervé

C., Berthon P. [Collections of human biological resources for research purposes: from regulations to the need of a guide of good practices]. La revue de medecine interne, 2003, $24: 803-814$

22. Louisot P. Rapport sur la protection intellectuelle des résultats de recherche sur le génome humain et les banques de cellules et de données sur l'ADN. Dictionnaire permanent de bioéthique et biotechnologies. Edition Législatives. Paris, Ministère de l'Enseignement supérieur et de la recherche. 1994: 9692-9695.

23. McEwen JE, Reilly PR. A survey of DNA diagnostic laboratories regarding DNA banking. Am J Hum Genet 1995; 56(6):1477-86.

24. Merz J, Leonard D, Miller E. IRB review and consent in human tissue research. Science 1999; 283:1647-1648. 
25. Morin, A.L., Consentement et recherche génétique : le cas des collections d'ADN. Droit et économie. 2001, 89: 40-57.

26. Moutel G, Leroux N, Herve C. Analysis of a survey of 36 French research committees on intracytoplasmic sperm injection. Lancet 1998; 351(9109):1121-3.

27. Moutel G., de Montgolfier S., Duchange N. et al. Study of the involvement of research ethics committees in the constitution and use of biobanks in France. Pharmacogenetics, 2004; 14: 195-198.

28. UNESCO. International declaration on human genetic data..adopted on 16 octobre 2003 by the 32nd session of the General Conference of UNESCO. 2003.

29. WMA. Helsinki declaration, Tokyo 1975, www.wma.net 
Table 1: Summary of the 28 answers to the questionnaire

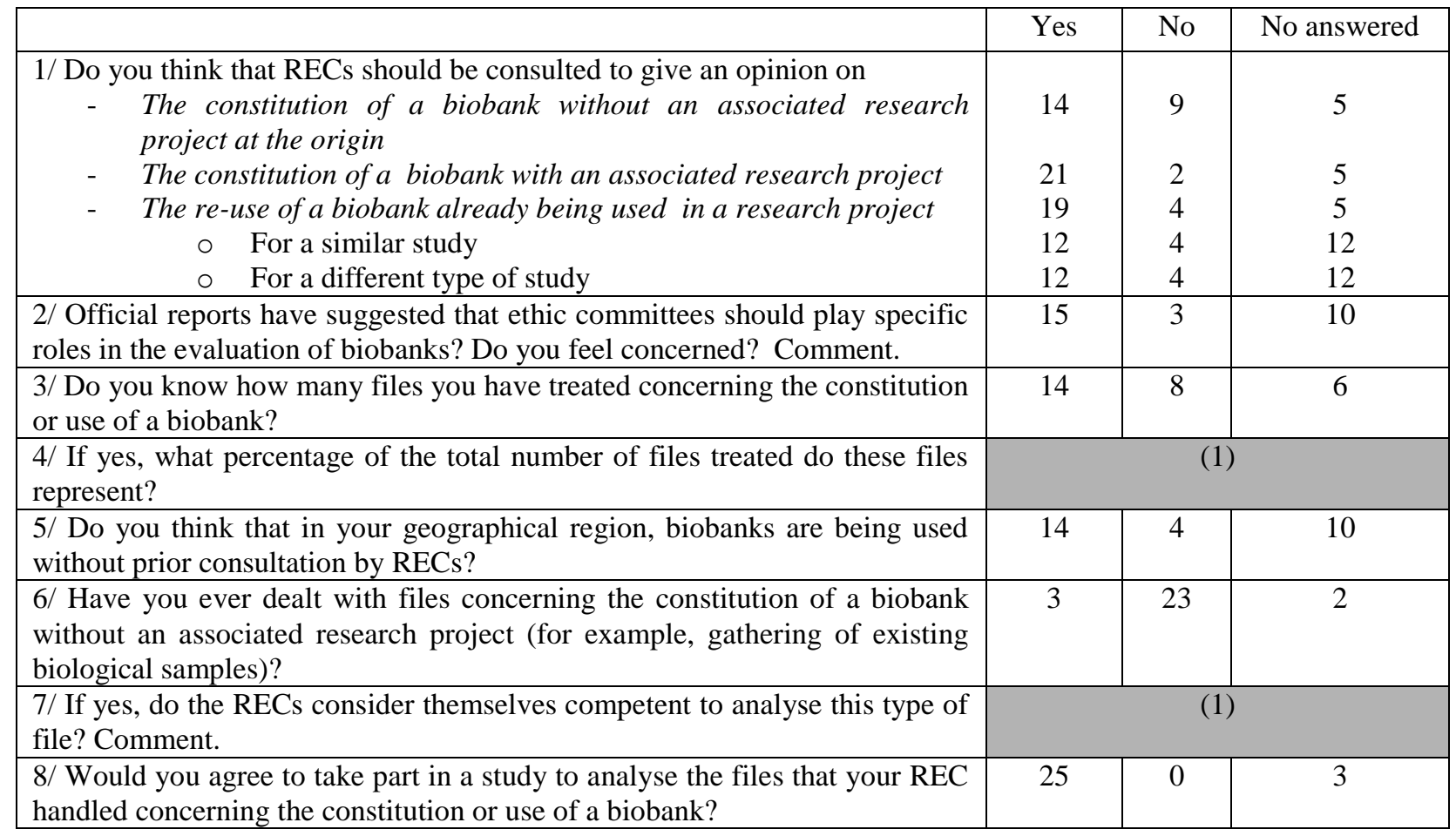

(1) These questions could not be treated quantitatively and are considered in the text 
Figure 1: Steps in the constitution and use of a biobank requiring REC evaluation under the criteria listed

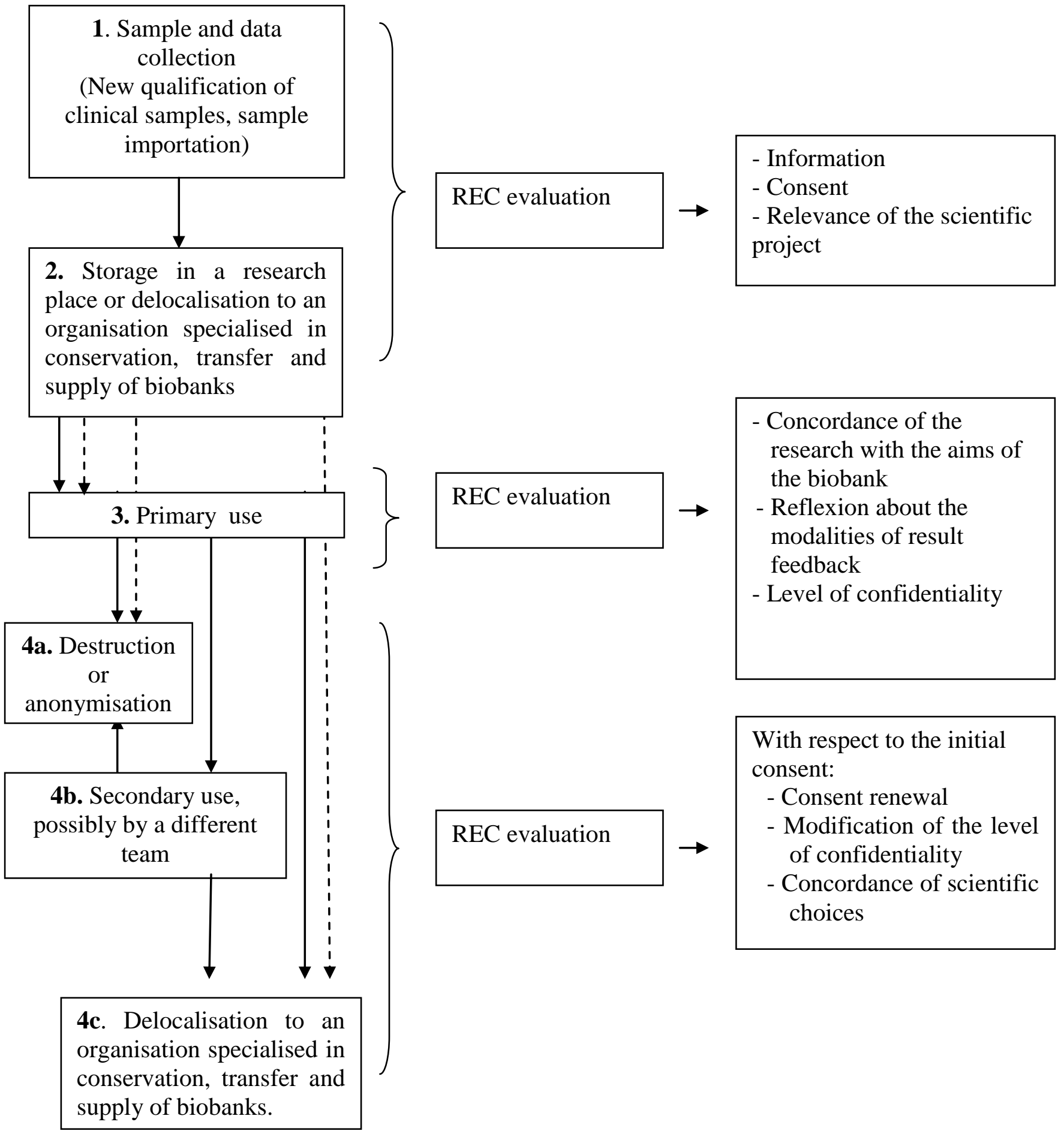

NB: Together with the evaluation by a REC, declarations should be made to the appropriate ministry, and authorisations concerning the treatment of individual data should be sought 